\title{
Stage B Chronic Lymphocytic Leukemia
}

National Cancer Institute

\section{Source}

National Cancer Institute. Stage B Chronic Lymphocytic Leukemia. NCI Thesaurus. Code C141210.

Findings: Lymphocytosis and adenopathy; Survival (months): 95. (from AJCC 8th Ed.) 